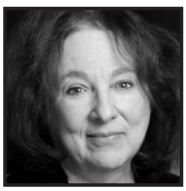

\title{
Commentary School, Family, and Community Partnerships
}

\author{
Joyce L. Epstein
}

\begin{abstract}
Joyce L. Epstein and her team at Johns Hopkins have been working with schools and school districts for two decades to guide them in developing school, family, and community partnerships that support students' education. In this interview, she describes the origin of her work with schools and families and how this led to the development of models and tools that schools can use to ensure that every family is involved in its children's education. She describes the importance of leadership, both at the school and district levels, as well as the use of evaluation tools to monitor a school's progress. Finally, she gives recommendations to districts and schools wishing to pursue this type of work.
\end{abstract}

-1))

How would you define "school, parent, and community partnerships"?

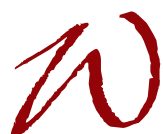

e say "school, family, and community partnerships" to reinforce the idea that schools have a role to play, families have roles to play, and the community has roles to play in helping students do their best in school. This focus on students contrasts with older and familiar terms of "parent involvement" or "parent engagement," which focused on parents. We incorporate these concepts under the word "partnership" because we want people to build relationships for good connections of home, school, and community. We say "family" even when we mean "parent," because many children have others in the family-grandparents, foster parents, and others-who are responsible for major connections with schools and teachers. We like the term "partnership" to help people understand the new way of thinking, even if they slip and say "parent involvement," which is an easy term to say. 
(1)) How did you become interested and committed to the development of school, family, and community partnerships?

My early work was on other topics of school improvement, starting with an early study of open and traditional schools in the mid-1970s. Open schools were becoming popular in Maryland. The leaders of a local school district asked for a study of whether students do better in open schools (e.g., classes in pods, few walls, high student decisionmaking, many student projects) or in traditional schools (e.g., regular classrooms with walls, more teacher-led lessons). We also explored whether students from differently structured families had higher achievement and more positive attitudes in open or traditional schools. What we learned was that families were important to all students, achievement was similar in both school organizations, but student attitudes about school were more positive in more open schools.

One result of the early study was to shine a spotlight on the role of family engagement at school and at home on student learning and development. Our work echoed decades of research that confirmed that families are important in their children's education. What we wanted to understand was: If families are so important in their children's education, how can all schools help all families support their children's success in school? This became a question of equity. The new question also redirected our research from prior studies focused on what families did or did not do on their own. New studies were needed on what teachers and administrators could do to engage more families with students on goal-linked activities at school and at home. In this way, we hoped to encourage a new line of research that recognized that well-planned programs of school, family, and community partnerships were a component of good school organization.

(1)) Can you talk about the model you have developed, a very interesting model I might add, to support student success in schools using school, family, and community partnerships?

In 1981, we started studies to understand family engagement. We wanted to be clear about what was "family involvement" and "parent involvement" in schools at the time. Our first study included some 600 elementary schools in Maryland. We studied what teachers do to engage families, what the concept meant to educators and parents, and how different practices affected students, teachers, and parents. It was the first large-sample, quantitative study focused deeply on school and family connections. 
When we were ready to report the results of this and other studies, we could not find a supporting theory that explained the patterns of results in our data. I developed an integrated theory based on prior psychological theories of child development and sociological theories of organizations that would represent the dynamic data we collected on the interactions of teachers and parents to increase student success in school (Epstein, 1987). My theory, Overlapping Spheres of Influence, includes an external model that shows three contexts-home, school, and community-to generate questions that ask: "Where do students learn and grow?" The answer has always been: at home, at school, and in the community. The external model is affected by forces such as time (grade level, history), philosophies, experiences, and practices that push the spheres of influence together for more connections or pull them apart for fewer connections.

The internal structure of the theoretical model identifies the potential relationships of parents or family members, teachers, and community members at the individual and institutional levels. This supports studies and measures of selected connections by educators, parents, and others at home, at school, and in the community. For example, on the individual level, the model would support a study of the form, function, and results of differently organized parent-teacher conferences (e.g., one teacher meeting with one parent to talk about a student). On the institutional level, the model would encourage a study of the design, implementation, and results of an open house night where all teachers and all parents come together to learn about the school program and grade-level or classroom activities.

The theoretical model diagrams the sociological and psychological forces that affect overlap of the contexts of home, school, and community and the interactions among all of the major people within these settings. The student is at the centre of the model. This is very important because we are trying to convey to educators, researchers, and policy leaders that the point of school, family, and community partnerships is the success of students. Our model posits that school, family, and community partners work together because of their common interests in helping more students-all studentssucceed to their full potential. The theoretical model does not assume positive results of partnerships, but supports studies of the nature of school, family, and community connections, interim results for participants, and ultimate results for students. Activities done well or poorly may produce positive or negative results. This makes the theory a useful base for many kinds of studies (Epstein, 2011). 
(1)) You have identified key areas of involvement. Can you talk about these?

In our early studies we were trying to understand the persistent questions: What is family engagement? What are effective practices of school, family, and community partnerships? Our data first identified four types of involvement, then five, and then six types of involvement. The types of involvement could be factor-analyzed so that we and others knew that there were distinct categories with identifiable practices, challenges, and results for students, as well as interim results for educators, parents, and for the community as a whole. The six types of involvement clarified that school programs could engage parents and others at home, at school, and in the community-in different ways and different places. This is important because parents and community partners cannot all come often to the school building. There are, indeed, other ways to share information and build connections in addition to meetings at school. The six types of involvement in my typology indicate that schools can develop practices on parenting-helping parents understand child and adolescent development [Type 1]; communicating-conducting two-way connections about school programs and children's progress [Type 2]; volunteering-encouraging parents' support and actions at school, in classrooms, at home, and as audience members of school activities [Type 3]; and learning at home-engaging parents with students on homework, talent development, course choices, and other aspects of student learning [Type 4]. It should be noted that Type 1 is about understanding the child as a child and children's development, whereas Type 4 is about understanding the child as a student and the curricular connections that help students learn subject-specific skills and extra-curricular connections that extend their abilities. Type 5 is decision makingensuring that parents' voices are heard in decisions that will affect children and the school climate. Type 6 is collaborating with the community-identifying resources in the community that will improve the school, students' experiences, and family needs. Type 6 also enables students to support the community with service learning projects, identify and solve community problems, or conduct philanthropic projects to benefit the community or citizens. To summarize, the six types of involvement provide a framework for school-based programs that implement goal-linked practices of family and community engagement to contribute to results for students.

We spent six or seven years of our early studies in trying to understand if and how the six types of involvement were separable. We wanted to improve on earlier labels about family engagement that were very confounded with terms such as parents as teachers and parents as learners. These terms could not be separated in many engagement activities. That is, sometimes parents are teachers and learners at the same time, as when they are volunteers. We wanted to develop a framework that was clearly 
defined by different activities, raised different challenges for engaging all families, and contributed to different results for students, parents, and teachers. You can see how this works in several tables in chapter 1 of the book, School, Family, and Community Partnerships: Your Handbook for Action (Epstein et al., 2009).

4)) You've made the point about the need for action teams. Can you talk a little bit about that?

Action teams are the heart of our approach to building partnership programs that work in schools and with districts and state departments of education. Many people will say to me, "Joyce, I know your six types of involvement." That is important, but just part of the story. The Action Team for Partnership (ATP) is the main structure we use to develop stable leadership for family and community engagement at the school level. The team of teachers, parents, and administrator, and at the high school level, students, uses the framework of six types of involvement to select goal-linked practices to reach out to engage all families. All voices-parents, teachers, administrators, and othersare represented in team decisions. The team's goal is to engage all families in ways that help their children do their best in school. This structure and purpose is critical to change the old way of thinking about parent involvement in schools. It still is common to assign one person (e.g., a parent liaison or coordinator, or the principal) to "deal with" parents. We learned early on that one person cannot conduct an effective partnership program. Rather, the ATP is designed to speak "partnerships" - parents or other family members, teachers, the administration, high school level students work together to decide for their own school, these grade levels, our population, in this community, "What is the best way to reach out to all families so that they are welcome at the school and respected as partners in their children's education? What activities among the six types of involvement will engage our families in ways that are linked to goals that are in our school improvement plan?" So, the team is key to the success of school-based partnership programs.

(1)) You've also talked about the utmost importance of including an evaluation dimension to the work. Can you talk a little bit about that?

Evaluation has, historically, been a missing link in programs of family and community engagement. Under the old way of thinking about parental involvement, educators and parents thought that anything they did was fine. If there was a good PTA at the school, that became the "program" for family engagement. Or, if the school organized 
an interesting family reading night, that activity represented the family engagement program. Most activities were evaluated in an old way with parent exit surveys that asked parents, "How did you like this event?" This strategy still can be useful, but we found that it is necessary to evaluate the quality and changes to major program structures and processes to establish and continually improve an effective and equitable partnership program. That includes measures of the organization and effectiveness of the team, teamwork, support from the principal and from a district leader, and the extent and results of outreach to all parents, including those who are most difficult to engage. Evaluations of quality and progress of essential elements of program development are needed to build a partnership program that is truly inclusive of all families and that supports and advances students' learning.

Now, we know that program evaluations are essential for strong and sustainable partnership programs. All of the components-teamwork, the framework of six types of involvement, the development of an action plan-are not made by magic. Every activity will not go well the first time it is implemented, and all parents will not be instantly involved. Partnership program development is an incremental progress. The only way to track progress and plan improvements is through evaluation.

This is difficult for schools because evaluations have not been an expected part of programs of family and community engagement, compared, let's say, to the clear necessity to evaluate a school's reading, math, and other programs. In colleagues' and my work with the National Network of Partnerships of Schools (NNPS), we conduct annual evaluations for and with each school or district to help them see the importance of evaluation. Wecollectdataonallmajorpartsofprogram developmentand reportresults of analyses back to the schools, districts, states, and organizations in the network. Then, they can see the importance of measuring and tracking the quality and progress of their efforts over time. We are trying to help leaders at all policy levels see that they can organize and continually improve their programs and practices of school, family, and community partnerships as a component of good school organization.

This also helps advance our research agenda. Data collected from schools in highly diverse communities across the country are better for addressing many new research questions than data collected from just one community. Thus, adding evaluation to the agenda for improving practice also has advanced this field of study. 
(1)) Can you give some examples of evaluations that get done in these instances? What do the tools look like?

There are many kinds of evaluations in our handbook, School, Family, and Community Partnerships: Your Handbook for Action. This includes inventories on family engagement based on the framework of six types of involvement. One inventory called Starting Points enables schools to take stock of present practices. No school in this country or other nations is at ground zero. Every school works in some ways with students' parents, but teachers may not know who they are reaching and who feels excluded. By completing Starting Points, an Action Team for Partnerships can review all of the activities they are currently conducting and discuss where improvements are needed to reach all families. For example, a team member may note: "We started with this good practice, but, look, we only do this in the early grades. What shall we do to extend our outreach?"

Another inventory in the Handbook is the Measure of School, Families, and Community Partnerships, which can be used after a year or so for ATPs to assess how extensively they are applying practices for the six types of involvement and engaging families across the grades.

A third inventory focuses on the quality of teamwork to keep the members of the ATP working well together. Members assess and discuss: Are team meetings well planned? Are people listening to each other? Do all team members have a chance to talk in our meetings? And so on. In this way, school teams can be reflective about how to strengthen teamwork.

These internal or "built-in" evaluations are conducted by the school or with district leadership. NNPS does not collect these data. They are for the use of any teams that use our Handbook, whether they are members of NNPS or not. We collect an annual UPDATE survey at the end of each school year with 10 or 12 scales that help members of NNPS measure the quality and progress of their programs. At the school level, this includes whether there is a functioning team that has the diverse members we require, whether the team meets regularly, whether and how the team is supported by the principal and district leaders, and how the team is reaching out to engage hard-toreach groups such as fathers, multicultural families, parents who work during the day, and other challenging groups of parents. We collect and analyze these data (see the annual reports on our website: www.partnershipschools.org in the section on Research and Evaluation). We also have a special benefit for districts in NNPS that have eight or more schools as network members. We provide these districts with an extra summary 
of their own schools' data. This helps NNPS members understand the importance of evaluating family and community engagement and helps district leaders consider how to help their schools move forward from year to year.

1)) Can you describe one interesting partnership, how it developed, and the successes that were gleaned from it?

In 2015, NNPS celebrated its 20th anniversary year as a network. We have learned a great deal over the years by working with hundreds of sites. In our current network, there are about 600 schools and 60 districts, a number of organizations, and some state departments of education. Each year we conduct a Partnership Awards program to recognize schools, districts, states, and organizations in NNPS that have implemented the essential elements of a research-based program - all the things that we just talked about-teamwork, the framework of six types of involvement, a clear focus on student outcomes, and outreach to all parents-and made them their own.

In NNPS, we have some districts that have mostly Latino families, and other network districts and schools with various percentages of African-American, AsianAmerican, and white families. Every district and school is a little different from the next. Also, in the United States, districts across the country are incredibly interesting. A district may have one school-for example, a K-12 school that serves all students, or a district may include several hundred schools. Leadership and programs will be very different in small and large districts and schools. NNPS Partnership Awards identify sites that submit evidence of the essential structures and processes and of place-based decisions about their goals for students and practices of family and community engagement. We post the awardees on our website with pictures of the school teams and district, state, and organization leaders so that others can see how strong programs can be developed in highly diverse communities.

One excellent partner in this work has been the school district in Pasco, Washington, which is over $70 \%$ Hispanic. Pasco is a major farm area that also includes several industries. There are 22 schools serving a large population of students (74\%) eligible for free or reduced-price meals. The district and all schools are members of NNPS, all have teams, write plans, and reach out to engage all families, regardless of language spoken at home. The district and schools have done remarkably well in continually improving their goal-linked partnership programs for increasing student success in school, and district and many schools have earned NNPS Partnership Awards. The national recognition from NNPS is important locally, but also helps others see that programs 
of family and community engagement can get stronger and more inclusive over time. When Pasco first joined NNPS, the schools were struggling to engage all families in productive ways and district leaders knew that more children could succeed in school and graduate from high school on time. The district and schools have made measurable progress over the years, bringing new schools into the Pasco network and NNPS, and establishing a "district culture of partnerships." The district and schools also have shared many of their best practices in NNPS annual books of Promising Partnerships Practices. These are posted on our website in the section Success Stories.

Pasco is one of many districts with schools in highly diverse communities that are showing that research-based structures and processes can be customized to help all schools engage parents, other family members, and community partners in ways that help improve students' reading, math, science, and other skills, attendance, behavior, health and-other important outcomes for student success. The sites in NNPS are very important because we, as researchers, can do studies that suggest "what works" to improve the quality of partnership programs, but it is necessary to see that research results can be translated into action. When we see evidence from the field in the award applications and in the books of Promising Partnership Practices, my staff and I really are inspired to keep working to learn, study, and produce stronger guidelines that are easily implemented in any community. The voices from the field are telling us, "Yes, research helps us design, develop, and reach out to our students' families in some very innovative ways." In NNPS, districts and schools learn from each other in this way and we, as researchers, also learn from the districts and schools about what succeeds well and what aspects of school, family, and community partnerships need more and better research.

By the way, "action" is my favorite word. People have been talking for a long time about the need for schools to organize partnership programs, but most educators put action on partnerships on a back burner while they address major school improvements such as new curricula, new instructional methods, and new assessments. Our and others' studies suggest that action on partnerships would help educators reach all other school improvement goals, as students do better with family and community support. So, we are trying to encourage schools to develop well-organized partnership programs at the same time that they work on other school improvements. 
1)) What are some of the challenges that recur over time for schools embarking on these kinds of actions and activities?

All districts and schools face countless challenges to reach all families and enable all students to succeed in school at their full potential. We joke with educators that they know that if they solve one challenge, another one will soon pop up. One recurring challenge that we face in districts and schools in NNPS is the rather dramatic and frequent change in leaders that occurs every year. Educators move, change positions, and retire, which affects leadership for partnerships, teams at schools, and other program components. Suddenly, a good leader is not there anymore. This happens in schools, districts, states, and organizations, with the potential of immediate disruptions to program plans and progress.

This is a big challenge in our work, as in all school improvement programs. We have studies with unique data from districts and schools that indicate that a consistent district leader for partnerships over three years or more helps schools measurably improve the quality and progress of their programs of family engagement compared to schools that do not have consistent district leadership for partnerships (Epstein, Galindo, \& Sheldon, 2011; Epstein \& Sheldon, 2016). Research shows that one of the most important variables that positively affects the quality of school's partnership programs is principal's leadership (Sanders \& Sheldon, 2009). Interestingly, we have found that a strong ATP can help a new principal continue to improve a partnership program, rather than halt progress.

From many districts in NNPS, we have learned that keeping records and photos of program development and having time for departing leaders to orient new leaders can help sustain and continually improve district and school partnership programs. We still need to make this easier. We are developing guidelines to help schools and districts plan for the inevitable transitions that will occur so that when a new district leader, principal, or team member enters the picture, they can pick up where the prior leader left off and not have to start over.

(1)) Do you have recommendations for schools wishing to embark on this kind of work?

After 20 years of networking and collecting data from sites in diverse communities, we are quite sure that any district and any school can embark successfully on this work. We know that an individual school leader can use published materials, our website, and Handbook for Action, whether they are members of NNPS or not. 
But, our data suggest that a more successful strategy is for districts to identify a leader for partnerships who will be able to help all schools in the district develop their partnership programs (not one school at a time). Parents who enroll their children in school should know that they will be partners with teachers in their children's education at all grade levels, not because one school leader thought partnerships were important. A district leader for partnerships whose responsibilities are codified in the district's strategic plan can become an expert on partnership program development and guide every preschool, elementary, middle, and high school to plan a researchbased, goal-linked program of family and community engagement. District leaders need to be able to say, "I understand that education is a shared responsibility of school, family, and community. We will help more students succeed in school if teachers, parents, and community members work together as partners in education." Although more and better research is always needed, that statement of purpose and intent now is attainable in districts and schools everywhere.

\section{Note}

Districts and schools are welcome to join NNPS for ongoing guidance and support. See Join NNPS at www.partnershipschools.org.

\section{References}

Epstein, J. L. (1987). Toward a theory of familyschool connections: Teacher practices and parent involvement (pp. 121-136). In K. Hurrelman, F. Kaufmann, \& F. Losel (Eds.), Social intervention: Potential and constraints. New York: DeGruyter.

Epstein, J. L. (2011). School, family, and community partnerships: Preparing educators and improving schools (2nd ed.). Westview Press.

Epstein, J. L., et al. (2009). School, family, and community partnerships: Your handbook for action (3rd ed.). Thousand Oaks, CA: Corwin Press.
Epstein, J. L., Galindo, C., \& Sheldon, S. B. (2011). Levels of leadership: Effects of district and school leaders on the quality of school programs of family and community involvement." Educational Administration Quarterly, 47(3), 462-495.

Epstein, J. L., \& Sheldon, S. B. (2016). Necessary but not sufficient: The role of policy for advancing programs of school, family, and community partnerships. Russell Sage Foundation Journal of the Social Sciences, 2 , 202-219.

Sanders, M. G., \& Sheldon, S. B. (2009). Principals matter: A guide to school, family, and community partnerships. Thousand Oaks, CA: Corwin Press. 


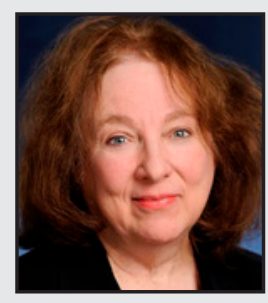

Joyce L. Epstein is Director of the Center on School, Family, and Community Partnerships and Professor of Education at Johns Hopkins University. In 1995, she established the National Network of Partnership Schools (NNPS), which provides professional development for leaders to develop researchbased programs of family and community engagement (www.partnershipschools.org). She has over 150 publications including School, Family, and Community Partnerships: Your Handbook for Action, 3rd Edition (2009) and a college textbook, School, Family, and Community Partnerships: Preparing Educators and Improving Schools, 2nd Edition (2011). Dr. Epstein was named a Fellow of the American Educational Research Association in 2009 and received the Elizabeth Cohen Award for Applied Research (2009) from AERA's Sociology of Education Special Interest Group. In all of her work, she is interested in the connections of research, policy, and practice. 